\title{
Diversity and Regeneration Status of Woody Species: The Case of Keja Araba and Tula Forests, South West Ethiopia
}

\author{
Getahun Yakob, Anteneh Fekadu \\ Southern Agricultural Research Institute, Hawassa, Ethiopia \\ Email: getahunyakob@gmail.com
}

Received 8 April 2016; accepted 22 April 2016; published 26 April 2016

Copyright (C) 2016 by authors and OALib.

This work is licensed under the Creative Commons Attribution International License (CC BY). http://creativecommons.org/licenses/by/4.0/

(c) (i) Open Access

\section{Abstract}

Deforestation and habitat fragmentation are the major environmental concerns in southwest Ethiopia. Understanding woody species diversity and socio-economic factors causing destruction of natural forests is crucial in the management of the remnant forest ecosystems. However, the forest in south west Ethiopia is poorly studied. This paper examines the diversity, regeneration status, socio-economic importance of the forests in Kaja Araba and Tula forests, southwestern Ethiopia. A systematic sampling strategy was used to collect vegetation data from the natural forests, while Participatory Rural Appraisal (PRA) method was employed to generate the socioeconomic data. A total of 60 square plots (30 for each forests measuring $10 \mathrm{~m} \times 10 \mathrm{~m}$ ) were established along line transects laid across the forests. Primary data were collected by field observation, semi-structured interview with key informants and discussion with relevant stakeholders. A total 51 woody species representing 25 families were found in the study area and of all the species $\mathbf{3 0}$ (59\%) were trees, $18(35 \%)$ trees/shrubs, and $3(6 \%)$ shrubs. The most species rich families were Rubiaceae, Fabaceae, Euphorbiaceae and Moraceae. The Shannon diversity and evenness of woody species in Keja Araba forest are 2.81 and 0.79 , respectively and in Tula forest they are 3.14 and 0.86, respectively. Millettia ferruginea is the most frequent and abundant species at Keja Araba natural forest, while Vepris dainellii and Phoenix reclinata are the most frequent and abundant woody species at Tula natural forest, respectively. The total basal area of woody species in Keja Araba forest is $2612 \mathrm{~m}^{2} \cdot \mathrm{ha}^{-1}$ and in Tula forest the value is $3751 \mathrm{~m}^{2} \cdot \mathrm{ha}^{-1}$. In Keja Araba forest, the species with the highest IVI value are Sapium ellipticum, and in Tula forest it is Schefflera abyssinica. The results on the importance value index (IVI) and DBH class distributions show that the species with low IVI value and poor regeneration status need to be prioritized for conservation. Data collected from the key informants reveal that the forest is the major sources of fuel wood (94\%), forest coffee and spices $(80 \%)$, construction material $(78 \%)$, timber $(60 \%)$ and farm implements (58\%). The forests are also sources of medicines, animal fodder, bee forage, handles tools and household utensils. Anthropogenic factors such as expansion of agricultural land, fuel wood collection, charcoal making, land use change by investors and settlements of people are responsible for destruction of natural forest in the study area, in descending order of severity. Thus, 
it is important to give conservation priority to the last Afromontane forest remnants in southwestern Ethiopia to achieve sustainable utilization of the forest ecosystems.

\title{
Keywords
}

\author{
Natural Forest, Woody Species, Basal Area, IVI, Conservation, Socio-Economic Importance
}

\author{
Subject Areas: Environmental Sciences
}

\section{Introduction}

Plant species diversity is a key issue of biological diversity. The diversity of woody species is fundamental to total forest biodiversity, because woody species provide resources and habitats for almost all other forest species [1] [2]. Human population growth and the demand for natural resources have put great pressure on the biodiversity wealth of the world through deforestation and habitat fragmentation [3] [4].

Ethiopia owns diverse vegetation resources that include high forests, woodlands, bushlands, plantations, and trees outside forests. These forest resources comprise huge wealth of biological resources. Diverse topography, soil and climate are the primary reason for the high diversity of these forests [5]. However, accelerated deforestation and habitat fragmentation are major environmental threats in the country and result in several socioeconomic and environmental challenges that have strongly affected the capacity of forests to provide ecosystem services [6] [7]. Agricultural expansion seems to be the number one reason for deforestation in the area, as in many tropical countries. The other major factors stated as responsible for destruction of natural forests are overexploitation without replanting for various purposes such as fuelwood, charcoal, construction material and timber [8].

Southern and southwestern parts of Ethiopia comprise most of the remaining natural forests of the country. The forest provide food, medicine, energy, fodder, farm implement and construction materials [9]. The forests hold diverse wild animal species, which play a significant role in gene flow between coffee shade trees and adjacent forest tree populations. The forests are also important resources for non-timber products and off-farm economic activities like honey and spices [10] [11]. Despite the fact that the study areas are so important to the country and the world at large, pressure exerted by anthropogenic factors is so significant and unless appropriate and immediate measures being taken the invaluable forest resource may be lost in a very short period of time.

Better understanding on woody species diversity, composition, population structure, and other ecological perspectives is very crucial for conservation and sustainable utilization of forest resources. Moreover, knowledge on woody species diversity and population structure is important for developing management strategies and setting priorities [5].

Many studies have been conducted in different parts of the country to investigate the population dynamics and regeneration ecology of forests including [12]-[23] and [5]. Despite of all these studies, there is little scientific information available on woody species diversity in natural forest in southwest Ethiopia. The flora of southwestern Ethiopia has been among the least known in the tropical Africa until recent years, mainly due to lack of access [19]. In order to ensure the conservation, management and sustainable utilization of these forests, describing the vegetation is urgently needed. Therefore, this research is aimed at: (i) assessing the diversity of woody species in the forests; (ii) characterizing the population structure and regeneration status of woody species; (iii) investigating the socio-economic importance of the forest for the surrounding communities.

\section{Materials and Methods}

\subsection{Study Area}

The study was conducted in Tula and Keja Araba forests located in Gimbo District, southwestern Ethiopia (Figure 1). Gimbodistrict is found in Kaffa Zone within the Southern Nations Nationality Regional State, 460 $\mathrm{km}$ southwest of Addis Ababa. It is situated between $07^{\circ} 00^{\prime}-7^{\circ} 25^{\prime} \mathrm{N}$ Latitude and $35^{\circ} 55^{\prime}-36^{\circ} 37^{\prime} \mathrm{E}$ Longitude and within altitudinal range from 1600 to $1900 \mathrm{~m}$. The topography is characterized by slopping and rugged areas 


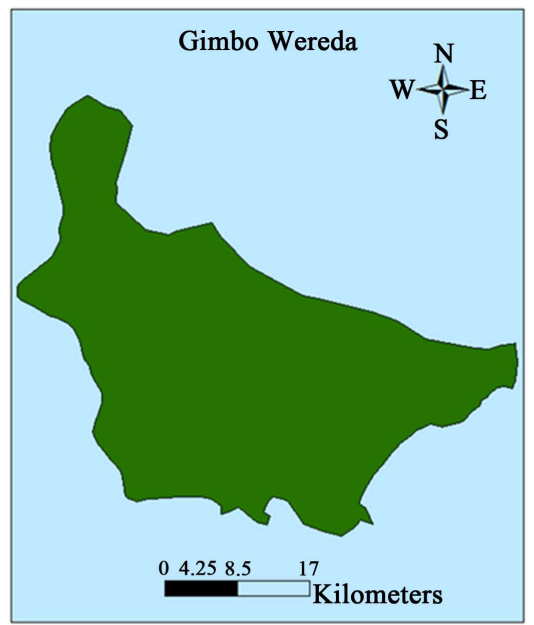

Coordinate System Information: Geographic Coordinate System Adindan, Meter Data source: EthioGIS
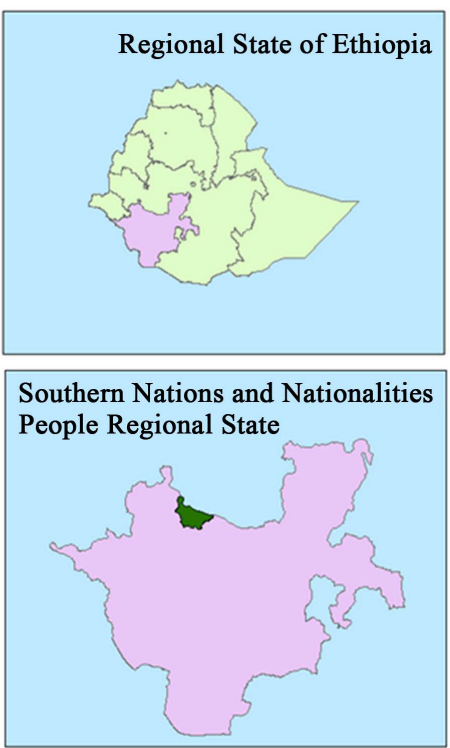

Figure 1. Map of study area.

with very little plain land. The area experiences one long rainy season, lasting from March/April to October. The mean annual rainfall ranges from $1710 \mathrm{~mm}$ to $1892 \mathrm{~mm}$. Over $85 \%$ of the total annual rainfall, with mean monthly values in the range of 125 - $250 \mathrm{~mm}$ occurs in the 8 months long rainy season. The mean temperature ranges from $18.1^{\circ} \mathrm{C}$ to $19.4^{\circ} \mathrm{C}$ [24]. The soils of the area are deep, clay red soils with an agric B-horizon dystricnitosols. The soils have good agricultural potentialities, good physical properties and uniform profile. They are porous, clay-to-clay loam in texture and have low base saturation with less than $5.5 \mathrm{pH}$ values and well drained [25]. Forests of both sites have been designated as National Forest Priority areas (NFPA).The inhabitants of the study area are from Kaffa and Amhara ethnic group, and they speak Kafignya and Amharic language respectively. The majority of the people are Orthodox Christians and few are Catholic and Muslims. The forest ecosystem in the area makes an important contribution to the livelihoods of people in the area in a variety ways. The forest provides shade for coffee and a variety of commercially valuable spices. The forests also supply rural communities with fuel wood and timber, which they use both for household consumption and for sale.

\subsection{Methods}

A systematic sampling design was used in this study to collect data on woody species. Following the line transect method described by Bullock [26] parallel line transects were laid across the forests. Plots $(10 \mathrm{~m} \times 10 \mathrm{~m})$ were established along the line transects at $300 \mathrm{~m}$ intervals. A total of 30 sampling plots, spaced $200 \mathrm{~m}$, were laid in the forests. In each plot, all woody species were identified by their local and/or scientific names and identities that help for identification were recorded and diameter at breast height (DBH, 1.3) for all woody species $\geq 5 \mathrm{~cm}$ was measured. Within the major plots by designating " $X$ " design, five $2 \mathrm{~m} * 2 \mathrm{~m}$ subplots were set up. These plots were used to collect two sets of vegetation data: 1) saplings (with dbh $<5 \mathrm{~cm}$ and $>1.5 \mathrm{~m}$ in height) and 2) seedlings. Key informants and sampled HHs were used to provide local names of the encountered woody species. After vernacular names were known, scientific names were identified with the help of publications of Flora of Ethiopia and Eritrea [27]-[31].

Participatory Rural Appraisal (PRA) method was used to collect socio-economic data following Martin [32] and Cunningham [33]. Data were collected by field observation, semi-structured interview with key informants and discussion with relevant stakeholders. Field observation was made on land use types, extent of soil erosion and forest degradation, forest management systems and human impacts on the forest ecosystems. A semi-structured/open-ended questionnaire was prepared in advance. Totally twenty key informants, ten from each sites, were selected and interviewed. During the interview with key informants, emphasis was given to issues related to the forests in order to get in-depth information about the past and present status, forest management systems, utilization and major threats. 


\subsection{Data Analysis}

Shannon-Wiener Diversity Index (H'), Simpson's diversity index (D) and Evenness or Equitability Index (E) were used to estimate the diversity of woody species in the natural forests. Shannon-Wiener Diversity Index (H') was calculated as $\mathrm{H}^{\prime}=-\sum p_{i} \ln p_{i}$, [34] where $P_{i}$ is the proportion of individuals, $n=$ Total number of individuals. Simpson's diversity was also calculated as:

$$
D=1-\sum p_{i}^{2}
$$

where $P_{i}=$ as described above. The measure of evenness (E) which is the ratio of observed diversity to maximum diversity is calculated as $\mathrm{E}=\mathrm{H}^{!} / \mathrm{H}_{\max }=\mathrm{H}^{!} / \mathrm{ln}$ [34]. The similarity in woody species composition between the forests was computed by using Sorensen coefficient of similarity $\left(S_{s}\right)$ index:

$$
S_{s}=2 a /(2 a+b+c)
$$

where $a=$ number of species common to both samples, $b=$ number of species in sample $1, c=$ number of species in sample 2 . The coefficient is multiplied by 100 to give a percentage [35]. The density and percentage frequency of woody species were calculated. The DBH data of trees and shrubs were categorized into eight classes, and presented by using histograms. Basal area of trees and shrubs with $\mathrm{DBH} \geq 5 \mathrm{~cm}$ was calculated. The Importance Value Index (IVI) [36] [37] for each woody species was computed using the following formula: Relative dominance $=($ basal area for a species/total basal area $) \times 100$.

Relative density $=($ number of individuals of a species/total number of individuals $) \times 100$, Relative frequency $=($ frequency of a species $/$ sum of all frequencies $) \times 100$.

Importance value Index $=$ Relative density + Relative dominance + Relative frequency

Microsoft Office Excel Software was used for the analysis of the socio-economic data and the results of the analysis were presented using descriptive statistics.

\section{Results and Discussion}

\subsection{Floristic Composition}

A total of 51 woody species representing 25 families were identified from Keja Araba and Tula forests. Rubiaceae, Fabaceae, Euphorbiaceae and Moraceae were the most abundant families. The value of woody species richness in natural forest at Keja Araba and Tula site were 40 and 47 respectively. From the total woody species, 30 (59\%) were trees, $18(35 \%)$ trees/shrubs, and 3 (6\%) shrubs.

\subsection{Similarity}

Similarity in woody species composition from the total species identified, 37 species were found in both Keja Araba and Tula forests (Appendix). The similarity in species composition between Keja Araba and Tula forests was 0.46 . The similarity coefficient was below 0.5 (maximum is 1.0), indicating that there is low similarity among the forests and each forest has its own characteristic species. This is mainly attributed to altitudinal and the extent of disturbance difference between the two sites.

\subsection{Diversity of Woody Species}

In order to get better picture on extent of woody species diversity, several diversity indices were employed for study sites. The value of diversity indices in natural forest at Keja Araba and Tula site were 2.81, 0.91, 0.79 and 3.14, 0.99, 0.86 for Shannon, Simpson and Evenness respectively (Table 1). The results indicated that the value

Table 1. Comparison of species richness and diversity indices of woody species among Keja Araba and Tula forests, Gimbo district.

\begin{tabular}{ccccc}
\hline Forest & Species Richness & & \multicolumn{2}{c}{ Diversity Index Values } \\
\cline { 3 - 4 } Keja Araba & 40 & Shannon & Simpson & 0.91 \\
Tula & 47 & 3.14 & 0.91 & 0.99 \\
\hline
\end{tabular}


of diversity indices of woody species at Tula forest were relatively higher than Kaja Araba forest. Site characteristic heterogeneity could be the reason for observed differences in woody species diversity. Agro-ecological factors such as altitude, temperature and soil quality could be a source of variation in plant diversity [38]. Besides, low human disturbance at Tula forest as it is less accessible site than Keja Araba could be another factor that generates difference in woody species diversity. Such results are consistent with study of Zegeye et al. [5] in northwestern Ethiopia, who reported negative effect of site accessibility on woody species diversity. Forest disturbance influences species through alteration and fragmentation of forests, which is a serious concern in the management tropical forests [39]. The evenness value (0.86) for Tula forest showed that there is more or less balanced distribution of individuals of different species than Keja Araba forest. On the other hand, the low evenness for Keja Araba forest with comparing to that of Tula indicated that there is unbalanced representation of individuals of different species because of high human disturbance as well as site and species characteristics. The reason for low evenness can be attributed to excessive disturbance, variable conditions for regeneration and over-exploitation of some species [20]. The diversity and evenness indices imply the need to conserve the forests at Keja Araba site from human disturbance.

\subsection{Frequency and Abundance of Woody Species}

Millettia ferrugineais the most frequent species recorded in $50 \%$ of the plots at KejaA raba natural forest. It is also the most abundant woody species followed by Phoenix reclinata and Sapium ellipticum (Table 2). Vepris dainelliiis the most frequent species recorded in $50 \%$ of the plots at Tula natural forest. Phoenix reclinata is the most abundant woody species followed by Vepris dainellii and Millettia ferruginea (Table 3). In addition to topographical, climatic and edaphic factors [40] [41], habitat preferences among the species, species characteristics for adaptation, degree of exploitation and conditions for regeneration could be the reasons for the variation in abundance and frequency woody species.

\subsection{Basal Area and IVI of Woody Species}

The total basal area of woody species in Keja Araba and Tula forests were 2611 and $3761 \mathrm{~m}^{2} \cdot \mathrm{ha}^{-1}$, respectively (Table 2 and Table 3). The reason for such variation is that Keja Araba forest highly disturbed than Tula due to its accessibility for road and town. In Keja Araba forest, the species with the highest basal area was Sapium ellipticum $\left(545.49 \mathrm{~m}^{2} \cdot \mathrm{ha}^{-1}\right)$, followed by Ritchie steudneri $\left(318.50 \mathrm{~m}^{2} \cdot \mathrm{ha}^{-1}\right)$, Schefflera abyssinica $(288.44$ $\left.\mathrm{m}^{2} \cdot \mathrm{ha}^{-1}\right)$, Milettia ferruginea $\left(232.08 \mathrm{~m}^{2} \cdot \mathrm{ha}^{-1}\right)$, Dracaena steudneri $\left(220.22 \mathrm{~m}^{2} \cdot \mathrm{ha}^{-1}\right)$, Schrebera alata $(176.71$ $\left.\mathrm{m}^{2} \cdot \mathrm{ha}^{-1}\right)$, Aningeria adolfi-friederici $\left(176.71 \mathrm{~m}^{2} \cdot \mathrm{ha}^{-1}\right)$ and Olea welwitschii $\left(166.90 \mathrm{~m}^{2} \cdot \mathrm{ha}^{-1}\right)$. Some species like Schefflera abyssinica, Schrebera alata, Aningeria adolfi-friederici and Olea welwitschii had high basal area because of their large size though they had low frequency and abundance. In Tula forest, the species with the highest basal area was Schefflera abyssinica $\left(1491.64 \mathrm{~m}^{2} \cdot \mathrm{ha}^{-1}\right)$, followed by Sapium ellipticum $\left(375.96 \mathrm{~m}^{2} \cdot \mathrm{ha}^{-1}\right)$, Olea welwitschii $\left(296.85 \mathrm{~m}^{2} \cdot \mathrm{ha}^{-1}\right)$, Ritchie asteudneri $\left(237.18 \mathrm{~m}^{2} \cdot \mathrm{ha}^{-1}\right)$, Ficussur $\left(222.39 \mathrm{~m}^{2} \cdot \mathrm{ha}^{-1}\right)$, Albizia gummifera $\left(183.48 \mathrm{~m}^{2} \cdot \mathrm{ha}^{-1}\right)$, Croton macrostachyus $\left(171.05 \mathrm{~m}^{2} \cdot \mathrm{ha}^{-1}\right)$ and Phoenix reclinata $\left(155.53 \mathrm{~m}^{2} \cdot \mathrm{ha}^{-1}\right)$. Some species like Schefflera abyssinica and Olea welwitschiih ad high basal area because of their large size and high abundance and frequency. To evaluate the importance of each species, the IVI was estimated for the woody species $(>5 \mathrm{~cm}$ ) recorded in the natural forest (Table 2 and Table 3). In Keja Araba forest, the species with the highest IVI value was Sapium ellipticum (45.18), followed by Milettia ferruginea (37.04), Ritchie asteudneri (27.95), Phoenix reclinata (27.33), Dracaena steudneri (21.34), Schefflera abyssinica (16.40), Croton macrostachyus (15.21), Olea welwitschii (10.41) and Cordia africana (9.11). The high IVI value of Phoenix reclinata and Cordia Africana was because of their high relative density and relative frequency, though they had low relative dominance/basal area. In Tula forest, the species with the highest IVI value was Schefflera abyssinica (51.26), followed by Phoenix reclinata (25.15), Vepris dainellii (21.01), Olea welwitschii (16.38), Milettia ferruginea (15.41), Sapium ellipticum (14.86), Ficussur (12.77), Croton macrostachyus (12.42) and Ficus palmata 11.30). The high IVI value of Vepris dainellii and Milettia ferruginea was because of their high relative density and relative frequency though they had low relative dominance. On the other hand, the high IVI value of Schefflera abyssinica and Sapium ellipticum were because of its high relative basal area though it had low relative density and relative frequency. Woody species with the highest importance values are those that exist in the greatest number or are of the greatest size- these are woody species that may have the greatest effect on the community. The IVI values can be used as an input for conservation strategies to protect woody species against anthropogenic factors [17]. The results suggest that the species having low IVI value should be attention for conservation. 
Table 2. Frequency, relative frequency, abundance, relative density, dominance, relative dominance and IVI of woody species $(\mathrm{dbh}>5 \mathrm{~cm})$ in Kaja Araba forest.

\begin{tabular}{|c|c|c|c|c|c|c|c|}
\hline Species Name & Frequency & $\begin{array}{c}\text { Relative } \\
\text { frequency (\%) }\end{array}$ & Abundance & $\begin{array}{c}\text { Relative } \\
\text { density (\%) }\end{array}$ & $\begin{array}{l}\text { Basal area } \\
\left(\mathrm{m}^{2} / \mathrm{ha}\right)\end{array}$ & $\begin{array}{c}\text { Relative } \\
\text { dominance (\%) }\end{array}$ & IVI \\
\hline Albizia gummifera & 2 & 1.67 & 2 & 1.01 & 29.06 & 1.11 & 3.79 \\
\hline Allophyllus macrobotrys & 2 & 1.67 & 3 & 1.52 & 0.92 & 0.04 & 3.22 \\
\hline Allophyllus rubifolius & 1 & 0.83 & 1 & 0.51 & 0.79 & 0.03 & 1.37 \\
\hline Allophylus abyssinicus & 1 & 0.83 & 1 & 0.51 & 5.73 & 0.22 & 1.56 \\
\hline Aningeria adolfi-friederici & 1 & 0.83 & 1 & 0.51 & 176.71 & 6.77 & 8.10 \\
\hline Canthium oligocarpum & 2 & 1.67 & 2 & 1.01 & 7.36 & 0.28 & 2.96 \\
\hline Cordia africana & 5 & 4.17 & 9 & 4.55 & 10.51 & 0.40 & 9.11 \\
\hline Croton macrostachyus & 6 & 5 & 13 & 6.57 & 95.10 & 3.64 & 15.21 \\
\hline Dracaena steudneri & 7 & 5.83 & 14 & 7.07 & 220.22 & 8.43 & 21.34 \\
\hline Ehretia cymosa & 3 & 2.50 & 4 & 2.02 & 10.88 & 0.42 & 4.94 \\
\hline Ficus ovata & 1 & 0.83 & 1 & 0.51 & 50.27 & 1.92 & 3.26 \\
\hline Ficus palmata & 2 & 1.67 & 2 & 1.01 & 10.12 & 0.39 & 3.06 \\
\hline Ficus sur & 5 & 4.17 & 6 & 3.03 & 28.93 & 1.11 & 8.30 \\
\hline Ficus thonningii & 1 & 0.83 & 1 & 0.51 & 3.14 & 0.12 & 1.46 \\
\hline Galinier asaxifraga & 2 & 1.67 & 2 & 1.01 & 2.22 & 0.08 & 2.76 \\
\hline Landolphia owarensis & 1 & 0.83 & 2 & 1.01 & 48.91 & 1.87 & 3.72 \\
\hline Lepidotrichilia volkensilia & 2 & 1.67 & 3 & 1.52 & 3.50 & 0.13 & 3.32 \\
\hline Macaranga kilmandscharica & 3 & 2.50 & 3 & 1.52 & 19.87 & 0.76 & 4.78 \\
\hline Maesa lanceolata & 1 & 0.83 & 1 & 0.51 & 4.15 & 0.16 & 1.50 \\
\hline Millettia ferruginea & 15 & 12.50 & 31 & 15.66 & 232.08 & 8.89 & 37.04 \\
\hline Olea welwitschii & 3 & 2.50 & 3 & 1.52 & 166.90 & 6.39 & 10.41 \\
\hline Phoenix reclinata & 11 & 9.17 & 28 & 14.14 & 105.13 & 4.03 & 27.33 \\
\hline Polyscias fulva & 1 & 0.83 & 1 & 0.51 & 9.62 & 0.37 & 1.71 \\
\hline Rhamnus prinoides & 1 & 0.83 & 1 & 0.51 & 4.91 & 0.19 & 1.53 \\
\hline Ritchiea steudneri & 8 & 6.67 & 18 & 9.09 & 318.50 & 12.20 & 27.95 \\
\hline Rothmannia & 1 & 0.83 & 1 & 0.51 & 1.13 & 0.04 & 1.38 \\
\hline \multicolumn{8}{|l|}{ Aurce lliformis } \\
\hline Sapium ellipticum & 14 & 11.67 & 25 & 12.63 & 545.49 & 20.89 & 45.18 \\
\hline Schefflera abyssinica & 4 & 3.33 & 4 & 2.02 & 288.44 & 11.04 & 16.40 \\
\hline Schrebera alata & 1 & 0.83 & 1 & 0.51 & 176.71 & 6.77 & 8.10 \\
\hline Syzygium guineense & 4 & 3.33 & 4 & 2.02 & 29.14 & 1.12 & 6.47 \\
\hline Vepris dainellii & 5 & 4.17 & 6 & 3.03 & 3.51 & 0.13 & 7.33 \\
\hline Vernonia amygdalina & 2 & 1.67 & 2 & 1.01 & 0.74 & 0.03 & 2.71 \\
\hline Vernonia auriculifera & 2 & 1.67 & 2 & 1.01 & 1.02 & 0.04 & 2.72 \\
\hline Total & 120 & 100 & 198 & 100 & 2611 & 100 & 300 \\
\hline
\end{tabular}


Table 3. Frequency, relative frequency, abundance, relative density, dominance, relative dominance and IVI of woody species $(\mathrm{dbh}>5 \mathrm{~cm})$ in Tula forest.

\begin{tabular}{|c|c|c|c|c|c|c|c|}
\hline Species & Frequency & $\begin{array}{c}\text { Relative } \\
\text { Frequency (\%) }\end{array}$ & Abundance & $\begin{array}{c}\text { Relative } \\
\text { Density (\%) }\end{array}$ & $\begin{array}{l}\text { Basal area } \\
\left(\mathrm{m}^{2} / \mathrm{ha}\right)\end{array}$ & $\begin{array}{c}\text { Relative } \\
\text { Dominance (\%) }\end{array}$ & IVI \\
\hline Albizia gummifera & 5 & 3.01 & 7 & 2.83 & 183 & 4.88 & 10.72 \\
\hline Allophyllus macrobotrys & 5 & 3.01 & 6 & 2.43 & 4 & 0.11 & 5.55 \\
\hline Apodytes dimidiata & 2 & 1.20 & 2 & 0.81 & 13 & 0.35 & 2.36 \\
\hline Canthium oligocarpum & 3 & 1.81 & 3 & 1.21 & 3 & 0.08 & 3.10 \\
\hline Celtis africana & 2 & 1.20 & 2 & 0.81 & 12 & 0.32 & 2.33 \\
\hline Chionanthus mildbraedii & 4 & 2.41 & 6 & 2.43 & 3 & 0.08 & 4.92 \\
\hline Clausena anisata & 3 & 1.81 & 4 & 1.62 & 4 & 0.11 & 3.53 \\
\hline Cordia africana & 4 & 2.41 & 4 & 1.62 & 7 & 0.19 & 4.22 \\
\hline Croton macrostachyus & 7 & 4.22 & 9 & 3.64 & 171 & 4.56 & 12.42 \\
\hline Dracaena steudneri & 6 & 3.61 & 8 & 3.24 & 18 & 0.48 & 7.33 \\
\hline Ehretia cymosa & 4 & 2.41 & 5 & 2.02 & 8 & 0.21 & 4.65 \\
\hline Ekebergia capensis & 2 & 1.20 & 2 & 0.81 & 62 & 1.65 & 3.67 \\
\hline Ficus palmata & 7 & 4.22 & 9 & 3.64 & 129 & 3.44 & 11.30 \\
\hline Ficus sur & 6 & 3.61 & 8 & 3.24 & 222 & 5.92 & 12.77 \\
\hline Ficus thonningii & 1 & 0.60 & 1 & 0.40 & 7 & 0.19 & 1.19 \\
\hline Galinier asaxifraga & 4 & 2.41 & 7 & 2.83 & 5 & 0.13 & 5.38 \\
\hline Illex mitis & 4 & 2.41 & 11 & 4.45 & 33 & 0.88 & 7.74 \\
\hline Justicia schimperana & 2 & 1.20 & 3 & 1.21 & 1 & 0.03 & 2.45 \\
\hline Lepidotrichili avolkensilia & 3 & 1.81 & 3 & 1.21 & 58 & 1.55 & 4.57 \\
\hline Macaranga kilmandscharica & 1 & 0.60 & 1 & 0.40 & 3 & 0.08 & 1.09 \\
\hline Margaritaria discoidea & 1 & 0.60 & 2 & 0.81 & 50 & 1.33 & 2.75 \\
\hline Millettia ferruginea & 11 & 6.63 & 18 & 7.29 & 56 & 1.49 & 15.41 \\
\hline Ocotea kenyensis & 1 & 0.60 & 1 & 0.40 & 2 & 0.05 & 1.06 \\
\hline Olea welwitschii & 8 & 4.82 & 9 & 3.64 & 297 & 7.92 & 16.38 \\
\hline Oxyanthus speciosus & 3 & 1.81 & 3 & 1.21 & 2 & 0.05 & 3.08 \\
\hline Phoenix reclinata & 12 & 7.23 & 34 & 13.77 & 156 & 4.16 & 25.15 \\
\hline Pittosporum abyssinicum & 1 & 0.60 & 1 & 0.40 & 1 & 0.03 & 1.03 \\
\hline Polyscias fulva & 4 & 2.41 & 4 & 1.62 & 58 & 1.55 & 5.58 \\
\hline Rhamnus prinoides & 6 & 3.61 & 11 & 4.45 & 40 & 1.07 & 9.13 \\
\hline Ritchie asteudneri & 4 & 2.41 & 5 & 2.02 & 237 & 6.32 & 10.75 \\
\hline Sapium ellipticum & 4 & 2.41 & 6 & 2.43 & 376 & 10.02 & 14.86 \\
\hline Schefflera abyssinica & 11 & 6.63 & 12 & 4.86 & 1492 & 39.78 & 51.26 \\
\hline Schrebera alata & 1 & 0.60 & 1 & 0.40 & 4 & 0.11 & 1.11 \\
\hline Syzygium guineense & 2 & 1.20 & 3 & 1.21 & 4 & 0.11 & 2.53 \\
\hline Teclea nobliis & 4 & 2.41 & 5 & 2.02 & 5 & 0.13 & 4.57 \\
\hline Vepris dainellii & 15 & 9.04 & 28 & 11.34 & 24 & 0.64 & 21.01 \\
\hline Vernonia amygdalina & 3 & 1.81 & 3 & 1.21 & 1 & 0.03 & 3.05 \\
\hline Total & 166 & 100 & 247 & 100 & 3751 & 100 & 300 \\
\hline
\end{tabular}




\subsection{Natural Regeneration and Diameter Class Distribution}

Figure 2 and Figure 3 presents the DBH class distributions of the most important woody species (having higher IVI values) in the forests. In Tula natural forest, Ritchie asteudneri, Vepris dainellii, and Ficus palmata was the most abundant in the lowest diameter class which suggests that they have good regeneration potential. Millettia ferruginea was dominated in both lowest and middle diameter classes. A seedling bank is crucial for old forests because it provides individuals that will eventually influence the composition of future plant communities [42]. In Keja Araba natural forest, Cordia africana was poorly represented in the middle and higher diameter classes.
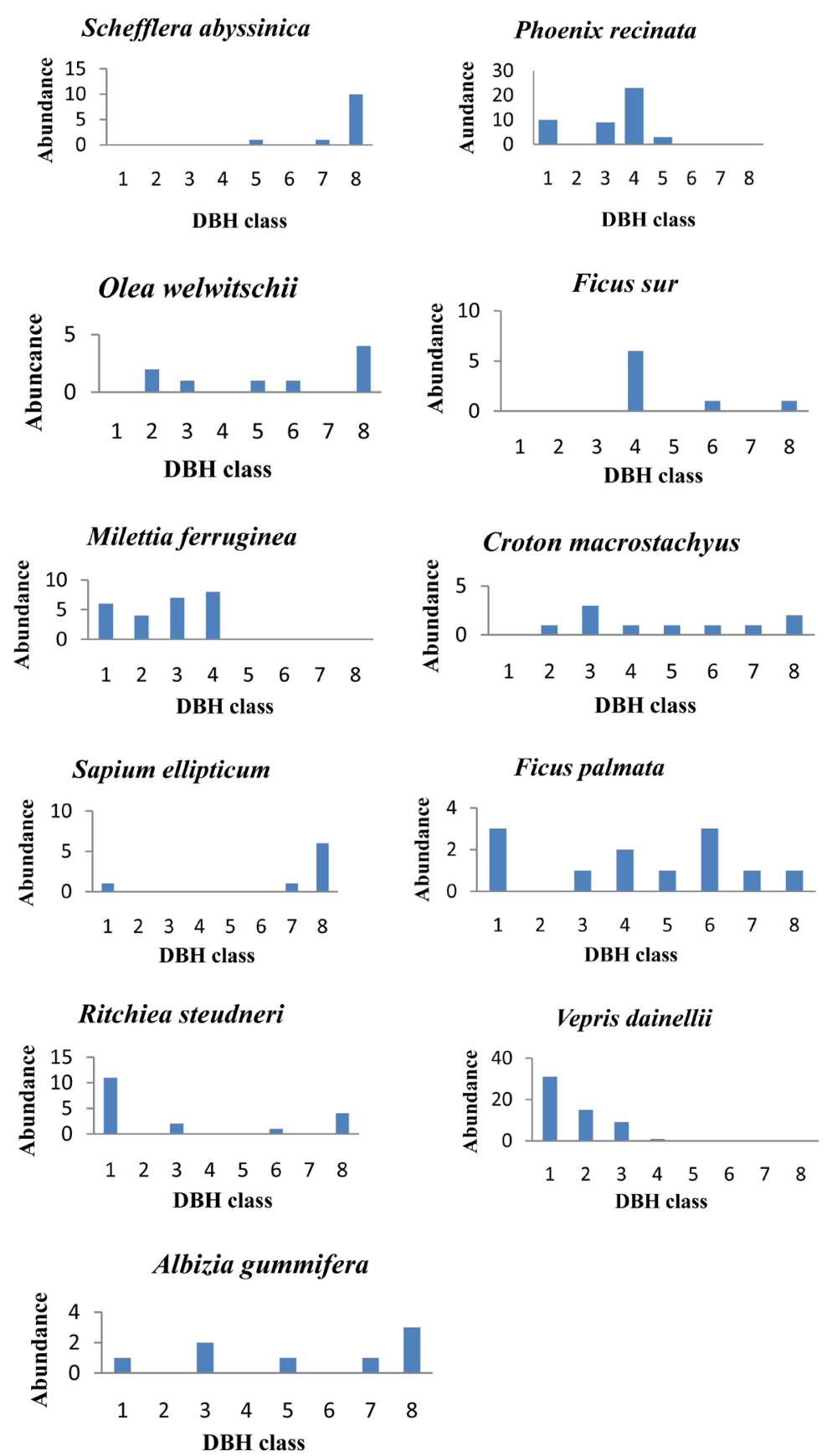

Figure 2. DBH class distributions of some important woody species (having higher IVI values) in Tula forests. (DBH classes: 1: $<5 \mathrm{~cm} ; 2: 5$ - $10 \mathrm{~cm}$; 3: $11-20 \mathrm{~cm} ; 4: 21$ - $30 \mathrm{~cm}$; 5: 31 - $40 \mathrm{~cm} ; 6: 41$ - $50 \mathrm{~cm} ; 7: 51$ - $60 \mathrm{~cm} ; 8:>60)$. 

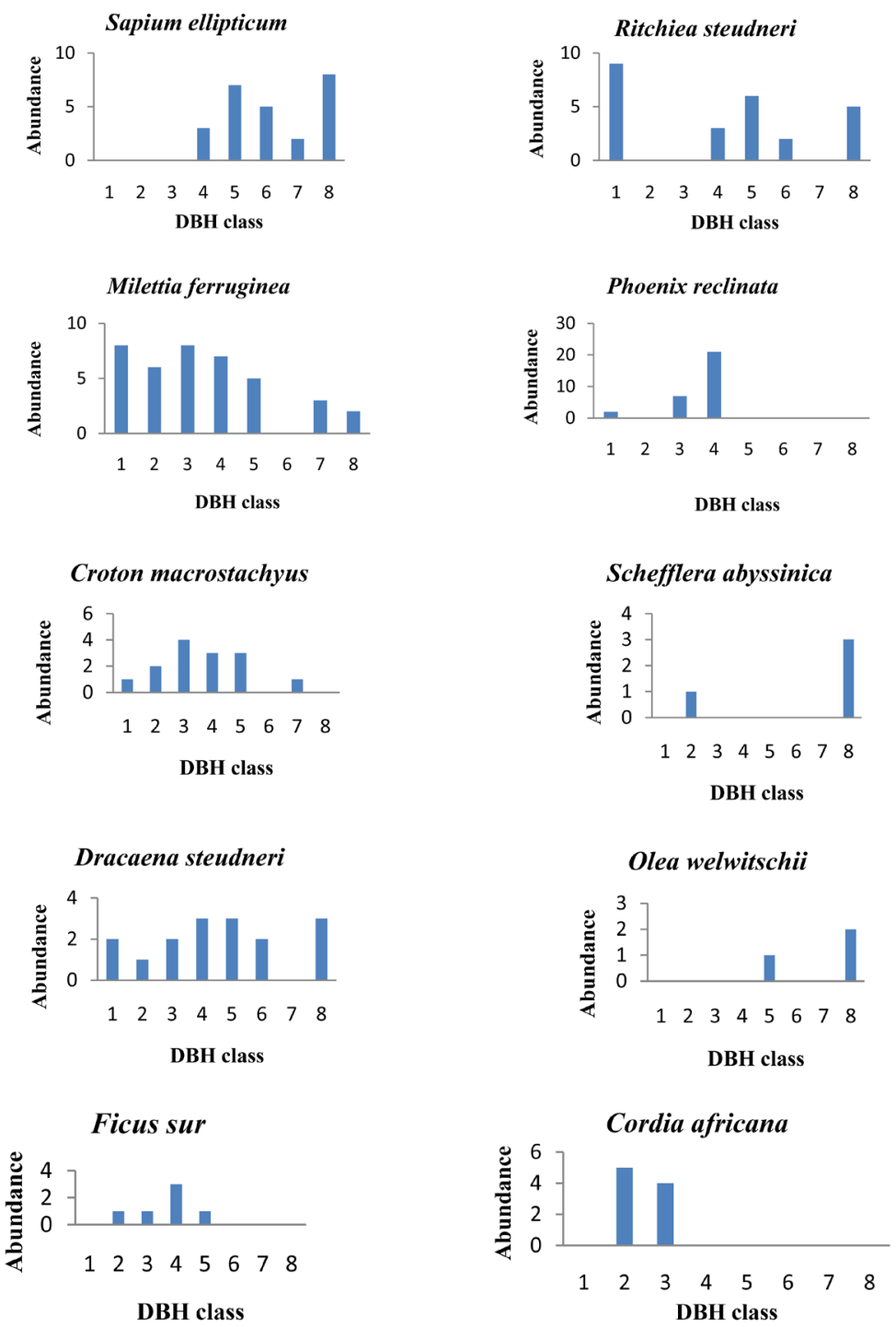

Ficus sur
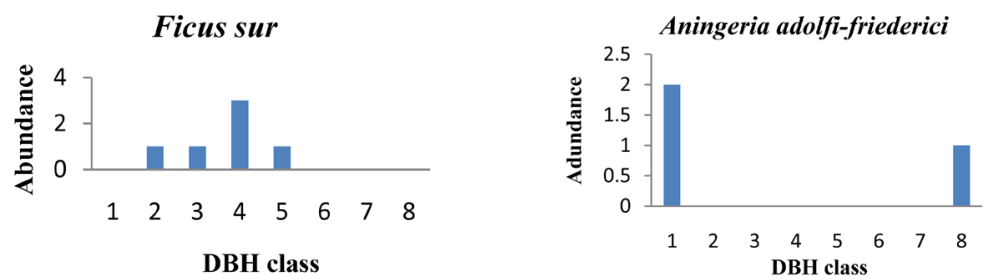

Figure 3. DBH class distributions of some important woody species (having higher IVI values) in Keja Araba forests. (DBH classes: 1: $<5 \mathrm{~cm}$; 2: 5 - $10 \mathrm{~cm}$; 3: 11 - $20 \mathrm{~cm}$; $4: 21$ - $30 \mathrm{~cm}$; 5: 31 $40 \mathrm{~cm} ; 6: 41$ - $50 \mathrm{~cm} ; 7: 51$ - $60 \mathrm{~cm} ; 8:>60)$.

This is because the removal of tree for timber and construction material and this phenomenon could lead to local extinction. Ritchie asteudneri and Millettia ferruginea were the two most abundant woody species represented in the seedling bank which suggests that they have good regeneration potential. Sapium ellipticum, Olea welwitschii and Schefflera abyssinica was dominated in higher diameter classes and poorly represented in the lower diameter classes. Both in Tula and Keja Arabaforest Schefflera abyssinicawas dominated in higher diameter classes and was not represented in the seedling bank. This is could be due to epiphytic recruitment regeneration strategy of the species. 


\subsection{Use Value and Threats of the Forest Resources}

The forest resource in the study area makes an important contribution to the livelihoods of the people. The responses from the key informants indicated that Kaja Araba and Tula forests are the major sources of fuel wood (94\%), forest coffee and spices (80\%), construction material (78\%), timber (60\%) and farm implements (58\%). They are also the sources of honey production (bee forage and hang up bee hives), medicines, animal fodder, handles tools and household utensils. The forests are recognized and designated by United Nations Educational, Scientific and Cultural Organization (UNESCO) in June 2010 as a biosphere reserve [43] and they are potential sites for scientific research, education and tourism industry. However, the forest cover of the area was decreasing alarmingly. According to the key informants, the main causes of forest degradation in the study area were expansion of agricultural land, fuel wood collection, charcoal making, land use change by investors (especially for coffee and tea plantation) and settlements of people, in descending order of severity. Over exploitation of the forests for wood products has resulted in the reduction of some of the economically important tree species like Cordia africana, Phoenix reclinata, Vepris dainellii and Milettia ferruginea.

\subsection{Planting and Retaining of Woody Species}

In the study area, there is a tradition of retaining woody species during conversion of forestland to agricultural land. Farmers have retained different woody species in their homegardens and agricultural landscape while converting the original forest to settlement areas. The number and type of species retained by respondents differed and some species (e.g. Millettia ferruginea, Vernonia amygdalina, Ficus sur, Croton macrostachyus and Sapium ellipticum) were more frequently retained than others.

In addition to retention of woody species, planting of different woody species is widely practiced in the study area. The frequency of planting of these species is quite different among households and some species (e.g. Coffea arabica, Albizzia gummifera, Persea americana, Erythrina spp., Cordia africana, and Eucalyptus camaldulensis) are more commonly planted than others. Besides control of soil erosion, trees retained and/or planted in the agroforestry systems provide various products such as fuelwood, construction material, farm implements, animal fodder and bee forage. They also serve as shade for coffee and spices, and live fences. Thus, the agroforestry systems reduce the pressure on the natural forests. The indigenous resource management systems and practices are of great importance and deserve special attention since they have the potential to promote the conservation of biodiversity. The indigenous/traditional resource conservation and management systems and practices of rural communities in Ethiopia promoted the conservation of genetic resources for centuries [44].

\section{Conclusion}

Tula and Keja Araba forests support high species richness and diversity. The similarity in species composition among the forests is low, indicating that each forest has its own characteristic species. Tula forest has higher diversity and evenness of woody species than Keja Araba, and this is attributed to the existence of heterogeneity in site characteristics and the extent of anthropogenic factors. The diversity and evenness indices indicate the need to give attention to reduce disturbance impact as a result of overexploitation of the natural forest in the area. The IVI values reveal the most ecologically important woody species in the forests and those to be prioritized for conservation. The DBH class distributions show that some species are in poor regeneration status due to human disturbance. The species having low IVI values and poor regeneration status need to be prioritized for conservation. The forests provide various products such as fuelwood, forest coffee and spices, construction material, timber, farm implements, medicines, animal fodder, bee forage and edible fruits. Despite their socio-economic and ecological importance, at present, the forests are under increased human pressure. Tree cutting for various purposes, farmland expansion and investment activities are the major threats to the forest resources.

\section{Recommendations}

In order to ensure sustainable utilization of the forest resources, the following recommendations are suggested.

- Research and/or development action is needed to stimulate regeneration by those species having low IVI values and poor regeneration status.

- It is necessary to promote improved agroforestry technologies that could help farmers to get woody and nonwoody forest products from their farmlands and hence, reduce the pressure on the natural forests. 
- Efforts should be made to provide the local communities with energy-saving stoves and alternative sources of energy in order to reduce the dependency on the forests for fuel wood.

- Due consideration should be given to compromise the issue of investment with sustainable utilization of forest resources in the area.

\section{Acknowledgements}

We are very grateful to Southern Agricultural Research Institute, Bonga Agricultural Research Center and Rural Capacity Building Project for financial supports. We also indebted to the staff of Bonga Agricultural Research Center and Gimboworeda Office of Agriculture for their cooperation. We would like to thank Ato Andualem Aklilu for preparation of location map.

\section{References}

[1] Whitmore, T.C. (1998) An Introduction to Tropical Rain Forests. Oxford University Press, New York.

[2] Huange, W., Pohjonen, V., Johansson, S., Nashanda, M., Katigula, M.I.L. and Luukkanen, O. (2003) Species Diversity, Forest Structure and Species Composition in Tanzanian Tropical Forests. Forest Ecology and Management, 173, 1124. http://dx.doi.org/10.1016/S0378-1127(01)00820-9

[3] Terborgh, J. and van Schaik, C.P. (1997) Minimizing Species Loss: The Imperative of Protection. In: Kramer, R., et al., Ed., Protected Areas and the Defense of Tropical Biodiversity, Oxford University Press, New York, 15-35.

[4] Noss, R.F. (1999) Assessing and Monitoring Forest Biodiversity: A Suggested Framework and Indicators. Forest Ecology and Management, 115, 135-146. http://dx.doi.org/10.1016/S0378-1127(98)00394-6

[5] Zegeye, H., Teketay, D. and Kelbessa, E. (2011) Diversity and Regeneration Status of Woody Species in Tara Gedamand Abebaye Forests, Northwestern Ethiopia. Journal of Forestry Research, 22, 315-328. http://dx.doi.org/10.1007/s11676-011-0176-6

[6] Badege, B. (2001) Deforestation and Land Degradation in the Ethiopian Highlands: A Strategy for Physical Recovery. Northeast African Studies, 8, 7-26. http://dx.doi.org/10.1353/nas.2005.0014

[7] Teketay, D. (2001) Deforestation, Wood Famine, and Environmental Degradation in Ethiopia's Highland Ecosystems: Urgent Need for Action. Northeast African Studies, 8, 53-76. http://dx.doi.org/10.1353/nas.2005.0020

[8] EPA (2003) State of Environment Report in Ethiopia: The Federal Democratic Republic of Ethiopia. Addis Ababa, Ethiopia.

[9] Gobeze, T., Bekele, M., Lemenih, M. and Kassa, H. (2009) Participatory Forest Management and Its Impacts on Livelihoods and Forest Status: The Case of Bonga Forest in Ethiopia. International Forestry Review, 11, 346-358. http://dx.doi.org/10.1505/ifor.11.3.346

[10] Adilo, M. (2007) The Contribution of Non-Timber Forest Products to Rural Livelihood in Southwest Ethiopia. MSc Thesis, Wageningen University, Wageningen.

[11] Melaku, E., Ewnetu, Z. and Teketay, D. (2014) Non-Timber Forest Products and Household Incomes in Bonga Forest Area, Southwestern Ethiopia. Journal of Forestry Research, 25, 215-223. http://dx.doi.org/10.1007/s11676-014-0447-0

[12] Hadera, G. (2000) A Study on the Ecology and Management of the Dess'a Forest in the Northeastern Escarpment of Ethiopia. MSc Thesis, Addis Ababa University, Addis Ababa.

[13] Bekele, T. (2000) Plant Population Dynamics of Dodonaea angustifolia and Olea europaea subsp. cuspidate in Dry Afromontane Forests of Ethiopia. PhD Thesis, Uppsala University, Uppsala.

[14] Aleligne, A. (2001) Diversity and Socio-Economic Importance of Woody Plants on the Peninsula of Zegie, Northwestern Ethiopia. MSc Thesis, Swedish University of Agricultural Sciences, Umeå.

[15] Taye, E. (2001) Report on Woody Plant Inventory of Yayu National Forest Priority Area, Zero Draft. IBCR/GTZ/ FGRCP, Addis Ababa.

[16] Tesfaye, G., Teketay, D. and Fetene, M. (2002) Regeneration of Fourteen Tree Species in Harenna Forest, Southeastern Ethiopia. Flora-Morphology, Distribution, Functional Ecology of Plants, 197, 461-474. http://dx.doi.org/10.1078/0367-2530-1210063

[17] Shibru, S. (2002) Inventory of Woody Species in Dindin Forest. Technical Report No. 01, IBCR/GTZ/FGRCP, Addis Ababa.

[18] Yeshitela, K. and Bekele, T. (2003) The Woody Species Composition and Structure of Masha-Anderacha Forest, South Western Ethiopia. Ethiopian Journal of Biological Science, 2, 31-48.

[19] Woldemariam, T. (2003) Vegetation of the Yayu Forest in SW Ethiopia: Impacts of Human Use and Implications for 
in Situ Conservation of Wild Coffea arabica L. Populations. PhD Thesis, University of Bonn, Bonn.

[20] Wassie, A., Teketay, D. and Powell, N. (2005) Church Forests in North Gonder Administrative Zone, Northern Ethiopia. Forests, Trees and Livelihoods, 15, 349-373. http://dx.doi.org/10.1080/14728028.2005.9752536

[21] Zegeye, H., Teketay, D. and Kelbessa, E. (2006) Diversity, Regeneration Status and Socio-Economic Importance of the Vegetation in the Islands of Lake Ziway, South-Central Ethiopia. Flora-Morphology, Distribution, Functional Ecology of Plants, 201, 483-498. http://dx.doi.org/10.1016/j.flora.2005.10.006

[22] Wassie, A., Sterck, F.J., Teketay, D. and Bongers, F. (2009) Effects of Livestock Exclusion on Tree Regeneration in Church Forests of Ethiopia. Forest Ecology and Management, 257, 765-772. http://dx.doi.org/10.1016/j.foreco.2008.07.032

[23] Tesfaye, G., Teketay, D., Fetene, M. and Beck, E. (2010) Regeneration of Seven Indigenous Tree Species in a Dry Afromontane Forest, Southern Ethiopia. Flora-Morphology, Distribution, Functional Ecology of Plants, 205, 135-143. http://dx.doi.org/10.1016/j.flora.2008.12.006

[24] Ersado, M. (2001) Inventory of Woody Species in Bonga Forest. Institute of Biodiversity Conservation and Research, Technical Report No. 1, Addis Ababa.

[25] CBFED (2004) Cordination Bureau of Finance and Economic Development. Regional Atlas. Southern Nations, Nationalities and People's Regional Sate Bureau of Statistics and Population. E.M Press, Awassa.

[26] Bullock, J. (1996) Plants. In: Sutherland, W.J., Ed., Ecological Census Techniques: A Handbook, Cambridge University Press, Cambridge, 111-138.

[27] Hedberg, I. and Edwards, S. (Eds.) (1989) Flora of Ethiopia and Eritrea, Vol. 3: Pittosporaceae to Araliaceae. The National Herbarium, Addis Ababa and the Department of Systematic Botany, Uppsala.

[28] Edwards, S., Tadesse, M., Demissew, S. and Hedberg, I. (Eds.) (2000) Flora of Ethiopia and Eritrea, Vol. 2, Part 1: Magnoliaceae to Flacourtiaceae. The National Herbarium, Addis Ababa and the Department of Systematic Botany, Uppsala.

[29] Hedberg, I., Edwards, S. and Nemomissa, S. (Eds.) (2003) Flora of Ethiopia and Eritrea, Vol. 4, Part 1: Apiaceae to Dipsacaceae. The National Herbarium, Addis Ababa and the Department of Systematic Botany, Uppsala.

[30] Hedberg, I., Friis, I. and Edwards, S. (Eds.) (2004) Flora of Ethiopia and Eritrea, Vol. 4, Part 2: Asteraceae (Compositae). The National Herbarium, Addis Ababa and the Department of Systematic Botany, Uppsala.

[31] Hedberg, I., Kelbessa, E., Edwards, S., Demissew, S. and Persson, E. (Eds.) (2006) Flora of Ethiopia and Eritrea, Vol. 5. Gentianaceae to Cyclocheilaceae. The National Herbarium, Addis Ababa University, Addis Ababa and Uppsala.

[32] Martin, G.J. (1995) Ethnobotany: A Methods Manual. Chapman and Hall, London. http://dx.doi.org/10.1007/978-1-4615-2496-0

[33] Cunningham, A.B. (2001) Applied Ethnobotany: People, Wild Plant Use and Conservation. Earthscan, London.

[34] Magurran, A.E. (1988) Ecological Diversity and Its Measurements. Chapman \& Hall, London, 179 p. http://dx.doi.org/10.1007/978-94-015-7358-0

[35] Kent, M. and Coker, P. (1992) Vegetation Description and Analysis: A Practical Approach. John Wiley \& Sons, Chichester, $363 \mathrm{p}$.

[36] Lamprecht, H. (1989) Silviculture in the Tropics: Tropical Forest Ecosystems and Their Tree Species-Possibilities and Methods for Their Long-Term Utilization. Federal Republic of Germany, Eschborn.

[37] Kent, M. and Coker, P. (1994) Vegetation Description and Analysis. John Wiley and Sons, Chichester.

[38] Hodel, U., Gessler, M., Cai, H.H., Thoan, V.V., Ha, N.V., Thu, N.X. and Ba, T. (1999) In Situ Conservation of Plant Genetic Resources in Home Gardens of Southern Vietnam. IPGRI, Rome, 106 p.

[39] Laurance, W.F. and Bierregaard, R.O. (1997) Tropical Forest Remnants: Ecology, Management, and Conservation of Fragmented Communities. University of Chicago Press, Chicago.

[40] Whittaker, R.J., Willis, K.J. and Field, R. (2003) Climatic-Energetic Explanations of Diversity: A Macroscopic Perspective. In: Blackburn, T.M. and Gaston, K.J., Eds., Macroecology: Concepts and Consequences, Cambridge University Press, Cambridge, 107-129.

[41] Currie, D.J., Mittelbach, G.G. and Cornell, H.V. (2004) Predictions and Tests of Climate Based Hypotheses of Broad-Scale Variation in Taxonomic Richness. Ecology Letters, 7, 1121-1134. http://dx.doi.org/10.1111/j.1461-0248.2004.00671.x

[42] Swaine, M.D., Liberman, D. and Hall, J.B. (1990) Structure and Dynamics of a Tropical Dry Forest in Ghana. Journal of Ecology, 71, 601-627. http://dx.doi.org/10.2307/2259737

[43] Berghöfer, A., Stadler, C. and Langdale, G. (2013) Sustaining Life: The Cloud Forests of Kafa. Marketing Concept for the Kafa Biosphere Reserve, Ethiopia. Report to NABU—The Nature and Biodiversity Conservation Union Germany, 
Berlin.

[44] Teketay, D. (1999) Past and Present Activities: Achievements and Constraints in Forest Genetic Resources Conservation in Ethiopia. In: Edwards, S., Demissie, A., Bekele, T. and Haase, G., Eds., Proceedings of the "National Workshop on Forest Genetic Resources Conservation: Principles, Strategies and Actions”, 21-22 June 1999, IBCR and GTZ, Addis Ababa, 49-72. 


\section{Appendix}

List of woody species encountered in Keja Araba and Tula forests with corresponding family and local names, life form and spatial distribution.

\begin{tabular}{|c|c|c|c|c|c|c|}
\hline Species name & Family name & Local name & $\begin{array}{l}\text { Life } \\
\text { form }\end{array}$ & $\begin{array}{l}\text { Keja } \\
\text { Araba }\end{array}$ & Tula & $\begin{array}{c}\text { Keja Araba* } \\
\text { Tula }\end{array}$ \\
\hline Albizia gummifera (J.F.Gmel.) C.A.Sm. & Fabaceae & Catto & $\mathrm{T}$ & 1 & 1 & 1 \\
\hline Albizia schimperiana Oliv. & Fabaceae & Коуо & $\mathrm{T}$ & 0 & 1 & 0 \\
\hline Allophyllus macrobotrys Gilg & Sapindaceae & Shahiyo & $\mathrm{S} / \mathrm{T}$ & 1 & 1 & 1 \\
\hline Allophyllus rubifolius (Hochst. erA. Rich). Engl. & Sapindaceae & Gurasedo & $\mathrm{S} / \mathrm{T}$ & 1 & 1 & 0 \\
\hline Allophylus abyssinicus (Hoschs.) Radlk. & Sapindaceae & Sheho & $\mathrm{T}$ & 1 & 1 & 1 \\
\hline Aningeria adolfi-friederici (Engl.) Robyns\& Gilbert & Sapotaceae & Kerero & $\mathrm{T}$ & 1 & 0 & 0 \\
\hline Apodytes dimidiata E. Mey-ex Am. & Icacinaceae & Wundefo & $\mathrm{T}$ & 0 & 1 & 0 \\
\hline Canthiu moligocarpum Hiern & Rubiaceae & Titiribo & $\mathrm{T}$ & 1 & 1 & 1 \\
\hline Celtis africana Burm.f. & Ulmaceae & Shishu & $\mathrm{T}$ & 0 & 1 & 0 \\
\hline Chionanthus mildbraedii (Gilg \& Schellenb.) Stearn & Oleacea & Shigio & $\mathrm{T} / \mathrm{S}$ & 1 & 1 & 1 \\
\hline Clausena anisata (willd.) Benth. & Rutaceae & Imbrito & $\mathrm{T} / \mathrm{S}$ & 1 & 1 & 1 \\
\hline Coffea arabica L. & Rubiaceae & Bunoo & $\mathrm{T} / \mathrm{S}$ & 1 & 1 & 1 \\
\hline Cordia africana Lam. & Boraginaceae & Di'oo & $\mathrm{T}$ & 1 & 1 & 1 \\
\hline Croton macrostachyus Del. & Euphorbiaceae & Wago & $\mathrm{T}$ & 1 & 1 & 1 \\
\hline Dracaena steudneri Engler & Dracenaceae & Yudo & $\mathrm{T} / \mathrm{S}$ & 1 & 1 & 1 \\
\hline Ehretia cymosa Thonn. & Boraginaceae & Wegamo & $\mathrm{T} / \mathrm{S}$ & 1 & 1 & 1 \\
\hline Ekebergia capensis Sparrman & Meliaceae & Ororo & $\mathrm{T}$ & 1 & 1 & 1 \\
\hline Ficus ovata Vahl & Moraceae & Shetopo & $\mathrm{T}$ & 1 & 0 & 0 \\
\hline Ficus palmata Forssk. & Moraceae & Shoto & $\mathrm{T}$ & 1 & 1 & 1 \\
\hline Ficus sur Forssk. & Moraceae & Chapharo & $\mathrm{T}$ & 1 & 1 & 1 \\
\hline Ficus thonningii Blume & Moraceae & Tigago & $\mathrm{T} / \mathrm{S}$ & 1 & 1 & 1 \\
\hline Galinier asaxifraga (Hochst.) Bridson & Rubiaceae & Dido & $\mathrm{T}$ & 1 & 1 & 1 \\
\hline Illex mitis (L.) Radlk & Meliaceae & Qeto & $\mathrm{T}$ & 1 & 1 & 1 \\
\hline Justicia schimperana (Hochst. Ex Nees) T.Anders. & Acanthaceae & Tumoga & S & 0 & 1 & 1 \\
\hline Landolphia owarensis Beauv. & Apocynaceae & Gebo & S & 1 & 0 & 0 \\
\hline Lepidotrichilia volkensilia (Gurke) Leory & Meliaceae & Keto & $\mathrm{T}$ & 1 & 1 & 1 \\
\hline Macaranga kilmandscharica Pax. & Euphorbiaceae & Shakaro & $\mathrm{T}$ & 1 & 1 & 1 \\
\hline Maesa lanceolata Forssk. & Myrsinaceae & Chego & $\mathrm{T} / \mathrm{S}$ & 1 & 1 & 1 \\
\hline Margaritaria discoidea (Baill.) Webster & Euphorbiaceae & Gibo & $\mathrm{T}$ & 0 & 1 & 0 \\
\hline Maytenus gracilipes subsp. Arguta (Loes.) & Celastraceae & Shiko & $\mathrm{S} / \mathrm{T}$ & 1 & 1 & 1 \\
\hline Millettia ferruginea (Hochst.) Bak. & Fabaceae & Bibero & $\mathrm{T}$ & 1 & 1 & 1 \\
\hline Ocotea kenyensis (Chiov.) Robyns \& Wilcz & Lauraceae & Najjo & $\mathrm{T}$ & 0 & 1 & 0 \\
\hline Olea welwitschii (Knobl.) Gilg \& Schellenb. & Oleacea & Yahoo & $\mathrm{T}$ & 1 & 1 & 1 \\
\hline
\end{tabular}




\section{Continued}

\begin{tabular}{|c|c|c|c|c|c|c|}
\hline Oxyanthus speciosus DC. & Rubiaceae & Aimato & $\mathrm{S} / \mathrm{T}$ & 1 & 1 & 1 \\
\hline Phoenix reclinata Jacq. & Arecaceae & Yebo & $\mathrm{T}$ & 1 & 1 & 1 \\
\hline Pittosporum abyssinicum Del. & Pittosporaceae & Sholloo & $\mathrm{T}$ & 0 & 1 & 0 \\
\hline Polyscias fulva (Hiern) Harms & Araliaceae & Keresho & $\mathrm{T}$ & 1 & 1 & 1 \\
\hline Prunus africana (Hook.f.) Kalkm & Rosaceae & Omo & $\mathrm{T}$ & 0 & 1 & 0 \\
\hline Rhamnus prinoides L' Herit. & Rhamnaceae & Gesho & $\mathrm{S} / \mathrm{T}$ & 1 & 1 & 1 \\
\hline Ritchie asteudneri Gilg, & Capparidaceae & Gabo & $\mathrm{S} / \mathrm{T}$ & 1 & 1 & 1 \\
\hline Rothmannia aurcelliformis (Hiern.) Robyns & Fabaceae & Dibo & $\mathrm{S}$ & 1 & 1 & 1 \\
\hline Rytignia neglecta (Hiern) Robyns & Rubiaceae & Netacho & $\mathrm{S} / \mathrm{T}$ & 0 & 1 & 0 \\
\hline Sapium ellipticum (Hochst.) Pax & Euphorbiaceae & Shedo & $\mathrm{T}$ & 1 & 1 & 1 \\
\hline Schefflera abyssinica (Hochyst. ex A. Rich) Harms & Araliaceae & Buto & $\mathrm{T}$ & 1 & 1 & 1 \\
\hline Schrebera alata (Hochst.) Welw. & Oleacea & Opo & $\mathrm{T}$ & 1 & 1 & 1 \\
\hline Syzygium guineense (Willd) DC. & Myrtaceae & Yino & $\mathrm{T}$ & 1 & 1 & 1 \\
\hline Teclea nobliis Del. & Rutaceae & Shengaro & $\mathrm{T}$ & 0 & 1 & 0 \\
\hline Vepris dainellii (Pichi-Serm.) Kokwaro & Rutaceae & Mengreto & $\mathrm{S} / \mathrm{T}$ & 1 & 1 & 1 \\
\hline Vernonia amygdalina Del. & Asteraceae & Grawo & $\mathrm{S} / \mathrm{T}$ & 1 & 1 & 1 \\
\hline Vernonia auriculifera Hiern & Asteraceae & Dengreto & $\mathrm{S} / \mathrm{T}$ & 1 & 1 & 1 \\
\hline Total & & & & 40 & 47 & 37 \\
\hline
\end{tabular}

Presence and absence of species is indicated by 1 and 0 , respectively, $\mathrm{T}=$ Trees, $\mathrm{T} / \mathrm{S}=$ Tree/Shrub, $\mathrm{S}=$ Shrub. 